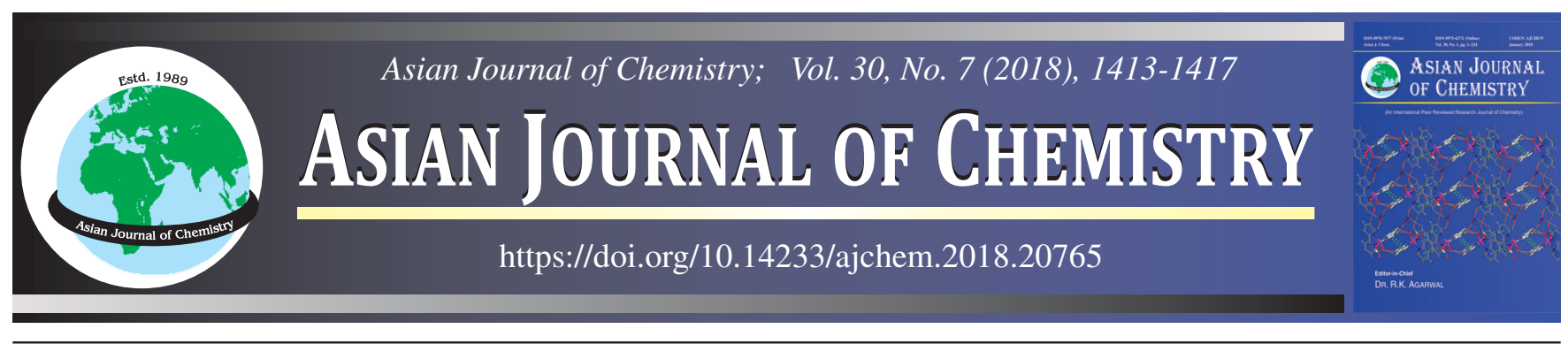

\title{
pH Dependence on the Synthesis of Gold Nanoparticles Capped Na-Citrate from Adsorbed Au(III) and Au(0) on Salicylic Acid Immobilized Mg/Al Hydrotalcite
}

\author{
P.A. Krisbiantoro, A. Muawanah, R.A. Almas and S.J. Santosa*
}

Department of Chemistry, Faculty of Mathematics and Natural Sciences, Universitas Gadjah Mada, Yogyakarta, Indonesia

*Corresponding author: Tel: +62 274 545188; E-mail: sjuari@ugm.ac.id

Received: 6 May 2017;

Accepted: 16 May 2018;

Published online: 31 May 2018;

AJC-18904

The investigation of $\mathrm{pH}$ dependence on the synthesis of gold nanoparticles capped Na-citrate from adsorbed $\mathrm{Au}(\mathrm{III})$ and $\mathrm{Au}(0)$ on salicylic acid immobilized hydotalcite had been carried out under ultrasound irradiation. Evidenced by UV-visible spectrophotometer, $\mathrm{pH}$ 3.0 revealed to be the optimum condition where gold nanoparticles show the evidence of surface plasmon resonance (SPR) at $547 \mathrm{~nm}$. The deprotonation of 1- and 2-carboxylic groups of capping agent citrate was lead to the forming of $\left[\mathrm{C}_{6} \mathrm{H}_{6} \mathrm{O}_{7}\right]^{2-}$ which acts as both reduction | and desorption agents of $\mathrm{Au}(\mathrm{III})$ and $\mathrm{Au}(0)$, respectively. Characterization using X-ray diffraction and transmission electron microscopy supported the successful synthesis of gold nanoparticles by the appearance of gold lattice index $(111 ; 200 ; 220$ and 311) and 2D nanoparticles image with the average size of $84.72 \mathrm{~nm}$.

Keywords: Gold nanoparticles, Hydrotalcite, Citrate, pH, Capping agent.

ᄂ _ - - - - - - - - - - - - - - -

\section{INTRODUCTION}

Gold nanoparticles are widely used in various applications, such as sensor [1], catalyst [2], drug delivery [3] and medical treatments [4-6]. These applications are known to be different from its bulk state or atoms due to the quantum size affect the electronic structures [7]. Therefore, the synthesis of gold nanoparticles from either primary or secondary resource and its modification to gain more feasibility have been fierce recently.

In differ with the primary resource; synthesis of gold nanoparticles from secondary resource requires gold's recovery agent before it can be synthesized using a capping agent. This includes all of the derivative compounds of phenol e.g. salicylic acid, gallic acid, ascorbic acid, tartaric acid, humic acid, fulvic acid etc. due to their negative value of redox potential. Each of these derivatives has its own number of carboxyl and phenolic groups at its own position on benzene ring. Support from the work of Ogata and Nakano [8], Santosa et al. [9] and Rahmayanti et al. [10] on the role of phenol derivative for gold recovery at low $\mathrm{pH}$, deprotonated carboxyl group $\left(-\mathrm{COO}^{-}\right)$and phenolic group $(-\mathrm{OH})$ are the responsible factors behind the binding of gold ions and its reduction into gold metal, respectively.

Salicylic acid as one of phenolic derivative has strong performance in reducing gold into gold metal and even nanoparticles $[11,12]$. It can also easily immobilized by host materials to increase its repeatability. Among many materials, recent eminent material that widely used as host material due to its feasibility is hydrotalcite, the layered double hydroxide anionic clay with net positive charge possessing its layer [13]. Thus, hydrotalcite is often employed for removal of anionic pollutants, for the removal of humic substances [13,14], dye waste [15-17] and heavy metals [18].

On the other hand, the most popular method for gold nanoparticles synthesis is Turkevich method. This in situ method employs citrate as both reducing and stabilizing agent of $\mathrm{AuCl}_{4}{ }^{-}$ and gold nanoparticles [19]. The synthesis reaction includes the oxidation on citrate and the reduction of auric salt with the respect resulting dicarboxy acetone and gold metal [20].

In this study, the influence of $\mathrm{pH}$ on the synthesis of gold nanoparticles and how it correlated to synthesis mechanism is presented. Initiated by gold's recovery at optimum $\mathrm{pH}$ using salicylic acid immobilized $\mathrm{Mg} / \mathrm{Al}$ hydrotalcite, gold nanoparticles were synthesized at various $\mathrm{pH}$ with sodium citrate as a capping agent. The synthesized gold nanoparticles were then characterized using UV-visible, X-ray diffractogram and transmission electron microscopy image.

\section{EXPERIMENTAL}

$\mathrm{Mg} / \mathrm{Al}$ hydrotalcite $(\mathrm{Mg} / \mathrm{Al})$ used in this study was prepared by adding drop-wise of $\mathrm{NaOH}$ solution $(0.50 \mathrm{M})$ into the mixture of $12.821 \mathrm{~g}(0.05 \mathrm{~mol}) \mathrm{Mg}\left(\mathrm{NO}_{3}\right)_{2} \cdot \mathrm{H}_{2} \mathrm{O}$ and $9.378 \mathrm{~g}$ $(0.025 \mathrm{~mol}) \mathrm{Al}\left(\mathrm{NO}_{3}\right)_{3} \cdot 9 \mathrm{H}_{2} \mathrm{O}$ under $\mathrm{N}_{2}$ atmosphere to the medium 
acidity equivalent to $\mathrm{pH} 10$. The formed solid was then vigorously stirred for $30 \mathrm{~min}$ and heated hydrothermally at $120^{\circ} \mathrm{C}$ for $5 \mathrm{~h}$. The precipitate was then cooled down at room temperature, washed by decarbonated water to neutral condition of the filtrate, filtered using $0.45 \mu \mathrm{m}$ paper and dried at $70{ }^{\circ} \mathrm{C}$ for $48 \mathrm{~h}$, respectively.

The immobilized salicylic acid on $\mathrm{Mg} / \mathrm{Al}$ hydrotalcite (Mg/Al HT-SA) was obtained with the respect by adding $0.10 \mathrm{~g}$ $\mathrm{Mg} / \mathrm{Al}$ hydrotalcite into $200 \mathrm{mg} \mathrm{L}^{-1}$ of salicylic acid at $\mathrm{pH}$ 5.0, shaken for $90 \mathrm{~min}$ and the solid was then filtered using $0.45 \mu \mathrm{m}$ paper.

All reagents in analytical grade, i.e. $\mathrm{HCl}, \mathrm{NaOH}$, salicylic acid, sodium citrate, $\mathrm{AuCl}_{4}^{-}, \mathrm{Mg}\left(\mathrm{NO}_{3}\right)_{2} \cdot \mathrm{H}_{2} \mathrm{O}, \mathrm{Al}\left(\mathrm{NO}_{3}\right)_{3} \cdot 9 \mathrm{H}_{2} \mathrm{O}$ were obtained from Merck Co Inc. (Germany) and are used without further purification.

Reductive adsorption of $\mathrm{AuCl}_{4}^{-}: 10 \mathrm{mg}$ of $\mathrm{Mg} / \mathrm{Al} \mathrm{HT}$ SA was added into $10 \mathrm{~mL}$ of $\mathrm{AuCl}_{4}^{-} 300 \mathrm{mg} \mathrm{L}^{-1}$ at $\mathrm{pH} 3.0$, shaken for $10 \mathrm{~h}$ and filtered using $0.45 \mu \mathrm{m}$ paper, respectively.

Synthesis of gold nanoparticles from adsorbed $\mathrm{AuCl}_{4}^{-}$ on Mg/Al HT-SA using sodium citrate as capping agent: A series of $10 \mathrm{~mL}$ of $100 \mathrm{mM}$ sodium citrate was prepared and their acidity was adjusted to $\mathrm{pH} 3.0,5.0,7.0,9.0$ and 11.0 by the addition of either $\mathrm{HCl}$ or $\mathrm{NaOH}$. Into every sodium citrate solution, $30 \mathrm{mg}$ of $\mathrm{Mg} / \mathrm{Al} \mathrm{HT}-\mathrm{SA}$ was poured and all mixtures were then irradiated with ultrasound batch for $3 \mathrm{~h}$. After ultrasound irradiation process, the obtained solid was then filtered using $0.45 \mu \mathrm{m}$ paper.

Detection method: Characterization of $\mathrm{Mg} / \mathrm{Al} \mathrm{HT}-\mathrm{SA}$ before and after reductive adsorption of $\mathrm{AuCl}_{4}^{-}$was performed using X-ray diffractometer and Fourier transform infrared spectroscopy. Meanwhile, the synthesized gold nanoparticles were characterized by UV-visible, XRD, FT-IR and TEM. The UV-visible spectra were scanned using Shimadzu UV-1700 Pharmaphec with the scanning wavelength ranging from 400$700 \mathrm{~nm}$. The FT-IR spectra were recorded using a Shimadzu Prestige-21. The sample was finely ground with an oven-dried spectroscopic grade $\mathrm{KBr}$ and pressed into a disc. The sample was scanned at $2 \mathrm{~cm}^{-1}$ resolution ranging from 4000 to 400 $\mathrm{cm}^{-1}$. The XRD measurements were run by Shimadzu XRD600 with Ni-filtered $\mathrm{Cu} \mathrm{K}_{\alpha}$ radiation $(\lambda=1.54060 \AA)$ at voltage $40 \mathrm{kV}$ and current $30 \mathrm{~mA}$. The sample was scanned in steps size 0.02 degree with the count time 0.24 second ranging from 0 to $70^{\circ}$. The TEM image was obtained using JEM $1400 \mathrm{JEOL} /$ EO. The sample was well prepared with ethanol as a dispersing agent. The image was taken under $8 \mathrm{M}$ pixels charge-coupled device (CCD) camera with the acceleration voltage $120 \mathrm{kV}$.

\section{RESULTS AND DISCUSSION}

By the addition of base solution $\mathrm{NaOH}$ to the mixture of $\mathrm{Mg}\left(\mathrm{NO}_{3}\right)_{2}$ and $\mathrm{Al}\left(\mathrm{NO}_{3}\right)_{3}$ with molar ratio 2:1 under $\mathrm{N}_{2}$ atmosphere, the solid of $\mathrm{Mg} / \mathrm{Al}$ can be obtained. The addition of $\mathrm{NaOH}$ was stopped at $\mathrm{pH} 10$ to obtain pure $\mathrm{Mg} / \mathrm{Al} \mathrm{HT}$ [13]. From FT-IR spectra, we obtained characteristic peaks of $\mathrm{Mg}$ / Al HT at 3464, 1635, 1381, 671 and $447 \mathrm{~cm}^{-1}$, which respectively correspond to $\mathrm{O}-\mathrm{H}$ stretching, $\mathrm{O}-\mathrm{H}$ bending, $\mathrm{N}-\mathrm{O}, \mathrm{N}=\mathrm{O}$ and $\mathrm{Mg}-\mathrm{O}-\mathrm{Al}$. The XRD measurements showed three main peaks at $10.94,22.38$ and $34.80^{\circ}$ with the respect indicates the characteristic basal spacing of 8.08 (003), 3.97 (006) and 2.57
(34.80) $\AA$. These peaks are in agreement with Santosa's report in 2008 [13] and matches with JCPDS 22-700.

The synthesized Mg/Al HT was then used to immobilize salicylic acid. The reaction based on the sorption ability of negatively charged of salicylic acid with positively charged of $\mathrm{Mg} / \mathrm{Al} \mathrm{HT}$. As the sorption medium acidity was adjusted to $\mathrm{pH}$ 5.0, the carboxyl group will be deprotonated into carboxyl anion due to $\mathrm{pKa}_{1}$ (-COOH deprotonation) of salicylic acid is around 2.97 [21], which at $200 \mathrm{mg} \mathrm{L}^{-1}$ equivalent to $\mathrm{pH} 2.90$. Through FT-IR spectra, the interaction between carboxyl anion with $\mathrm{Mg} / \mathrm{Al} \mathrm{HT}$ was evidenced by the appearance of new peaks at 2931 and $1265 \mathrm{~cm}^{-1}$ which associated to the presence of $\mathrm{C}-\mathrm{O}$ from phenolic group and $\mathrm{C}-\mathrm{H} s p^{2}$ from benzene ring of salicylic acid, respectively. The sorption also supported by the reduction of $\mathrm{N}-\mathrm{O}$ vibration band intensity at $1381 \mathrm{~cm}^{-1}$. This might be due to protonation process at the layer of $\mathrm{Mg} / \mathrm{Al} \mathrm{HT}$, which the protons are coming from the leached $\mathrm{H}^{+}$from the carboxyl groups of salicylic acid. Meanwhile, the XRD diffractogram showed similar peaks refer to the prior $\mathrm{Mg} / \mathrm{Al}$ HT diffractogram. This means that salicylate anion is only adsorbed onto the surface of $\mathrm{Mg} / \mathrm{Al} \mathrm{HT}$ and was not entered the layers.

Sorption of $\mathbf{A u C l}_{4}{ }^{-}$: The sorption of $\mathrm{AuCl}_{4}{ }^{-}$was performed at optimum condition ( $\mathrm{pH} 3.0)$ where gold ion and $\mathrm{Mg} / \mathrm{Al}$ HT-SA possessing negatively and positively charged, respectively. At this $\mathrm{pH}$, gold ion is at chloride complex form and easier to adsorbed than its hydrolyzed form. In opposite, $\mathrm{Mg} / \mathrm{Al}$ HT-SA will positively charged due to $\mathrm{pKa}_{2}(-\mathrm{OH}$ deprotonation) of salicylic acid at the surface of $\mathrm{Mg} / \mathrm{Al} \mathrm{HT}$ is about 13.74 [21], which at $200 \mathrm{mg} \mathrm{L}^{-1}$ will equivalent to $\mathrm{pH}$ 8.28. This means, under $\mathrm{pH} 8.28$ the $-\mathrm{OH}$ groups of immobilized salicylic acid will partially positively charged due to protonation at the low $\mathrm{pH}$.

The sorption process occurs when the $\mathrm{Cl}$ of $\mathrm{AuCl}_{4}^{-}$is electrostatically interacted with $-\mathrm{OH}$ from salicylic phenolic group due to the great difference of electronegativity between $\mathrm{Cl}$ and $\mathrm{H}$. At this point, phenolic group is not only responsible for sorption process, but also acts as reducing agent $[11,12]$. Therefore, most of the $\mathrm{AuCl}_{4}{ }^{-}$will be reduced into $\mathrm{Au}(0)$ constantly after adsorbed. Characterization of the Mg/Al HT-SA after sorption process showed the presence of $\mathrm{Au}(0)$ face centered cubic peaks at $2 \theta: 37.39,43.61,63.88$ and $76.94^{\circ}$, indicating the reflection planes of (111), (200), (220) and (311). This diffractogram is matched well with the standard in JCPDS 04-784. The sorption process was also confirmed through FT-IR spectra by the sifting of O-H stretching from 3464 to $3433 \mathrm{~cm}^{-1}$. This band belongs to $\mathrm{O}-\mathrm{H}$ of phenolic group which responsible for the binding of $\mathrm{AuCl}_{4}^{-}$. Meanwhile, the reduction process in FT-IR spectra can be seen from the band disappearance of the peak at $1265 \mathrm{~cm}^{-1}$, which belong to $\mathrm{C}-\mathrm{O}$ from the phenolic group. The absence of $\mathrm{C}-\mathrm{O}$ revealed the oxidation process of the phenolic group into ketone to reduce the $\mathrm{AuCl}_{4}^{-}$.

Synthesis of gold nanoparticles: Synthesis of gold nanoparticles from adsorbed $\mathrm{Au}(0)$ and $\mathrm{Au}(\mathrm{III})$ on $\mathrm{Mg} / \mathrm{Al}$ HT-SA were carried out using Turkevich method [19,20]. This method used citrate as a capping agent and performed under ultrasound irradiation. The negatively charged citrate ion at gold's surface will lead to the repulsive interaction to another capped gold. Therefore, the presence of citrate ion can stabilize through 
limiting the size of gold and prevent the nanoparticles from agglomeration.

Effect of $\mathrm{pH}$ to the synthesis of gold nanoparticles: Medium acidity plays an important role in the synthesis of gold nanoparticles. According to the report by Patungwasa and Hodax [22], medium acidity can highly affect the size of nanoparticles, its distribution and its morphology. The effect of medium acidity conducted by adding $30 \mathrm{mg} \mathrm{Mg} / \mathrm{Al}$ HT-SA with $10 \mathrm{~mL}$ sodium citrate with the medium acidity varied at 3.0, 5.0, 7.0, 9.0 and 11.0. To obtain more dispersed and small size of nanoparticles, in this study ultrasound batch was used during synthesis process [23]. As this study used a weak organic acid citrate to synthesis the gold nanoparticles, the reaction will immensely depend to the $\mathrm{pKa}$ of citrate. The $\mathrm{pKa}$ values in accordance to $\mathrm{pH}$ is given in Table-1. Through the basic calculation of the pKa [24], the deprotonation of the 2-, 1- and 3-carboxylate will sequentially occur at $\mathrm{pH} 2.05,2.9$ and 3.7. Therefore, before the data were obtained it has been hypothesized that the optimum $\mathrm{pH}$ of desorption process will occur at the $\mathrm{pH}$ ranging from 2.0 to 5.0.

\begin{tabular}{cccc}
\multicolumn{5}{c}{ TABLE-1 } \\
& $\begin{array}{c}\text { pKa VALUE OF THE CITRATE IN REGARD } \\
\text { TO THE DEPROTONATION pH }\end{array}$ \\
\hline $\mathrm{pKa}$ & $\mathrm{pKa}$ value & $\begin{array}{c}\text { Carboxyl } \\
\text { position }\end{array}$ & $\mathrm{pH}$ \\
\hline $\mathrm{pKa}_{1}$ & 3.1 & $2-$ & 2.05 \\
$\mathrm{pKa}_{2}$ & 4.8 & $1-$ & 2.90 \\
$\mathrm{pKa}_{3}$ & 6.4 & $3-$ & 3.70 \\
\hline
\end{tabular}

Characterization after synthesis process: The synthesized gold nanoparticles in the citrate solution were characterized using UV-visible spectrometer. Through UV-visible, the presence of gold nanoparticles can be detected by the surface plasmon resonance (SPR) of gold at wavelength 500-560. According to Dhawan and Muth [25], the absorbance at this wavelength indicates the free electrons at conductance band of gold nanoparticles. From the scanned absorbance, there is a clear indication on each of pH 3.0 and 5.0 at wavelength 547 and $549 \mathrm{~nm}$, respectively. This indicates that at $\mathrm{pH} 3.0$ and 5.0 , the gold nanoparticles were formed. The sharper indention at $\mathrm{pH} 3.0$ suggests the higher amount of synthesized gold nanoparticles instead of $\mathrm{pH}$ 5.0. Surprisingly, this correlated well with the value of citrate's $\mathrm{pKa}$ and in agreement with what we hypothesized before the study. As explained before, at $\mathrm{pH} 3.0$ two carboxyl groups will be deprotonated and form two carboxylates anion $\left(-\mathrm{COO}^{-}\right)$. These anions are the responsible functional groups on the desorption process of $\mathrm{Au}(0)$ and $\mathrm{Au}$ (III) from $\mathrm{Mg} / \mathrm{Al} \mathrm{HT}$-SA. The desorbed $\mathrm{Au}(0)$ will constantly electrostatically capped by negatively charges of carboxylate groups of citrate ion. Meanwhile, the small amount $\mathrm{Au}(\mathrm{III})$ that were not reduced by salicylic acid will be reduced by phenolic group of citrate and capped after $\mathrm{Au}(0)$ was formed. The absorbance also tends to increase by the increasing of $\mathrm{pH}$. This might be due to the colour of the citrate solution after irradiation process tends to intense red by the increasing of the $\mathrm{pH}$.

The presence of gold nanoparticles was also supported by the visual colour of the citrate solution after irradiation process. According to Philip [26], the colour of citrate solution after synthesis process of gold nanoparticles will change into characteristic red colour. Fig. 1 shows the different colour of different medium acidity of the citrate solution. The dark-red colour tends to decrease by the increasing of $\mathrm{pH}$. By this visual characterization can be seen that $\mathrm{pH} 3.0$ has the clearest red colour, means that gold nanoparticles were in abundant amount at this $\mathrm{pH}$.

After optimum $\mathrm{pH}$ was obtained, the red colloid that contains gold nanoparticles was centrifuged at $12.500 \mathrm{rpm}$ and characterized using UV-visible, XRD, FT-IR and TEM. UV-visible spectra after centrifugation revealed the vanishing characteristic absorbance of gold nanoparticles at $542 \mathrm{~nm}$ (Fig. 2). This means that gold nanoparticles were well separated from the solution and perfectly capped by citrate. Through XRD diffractogram, the absence of Mg/Al HT-SA was confirmed

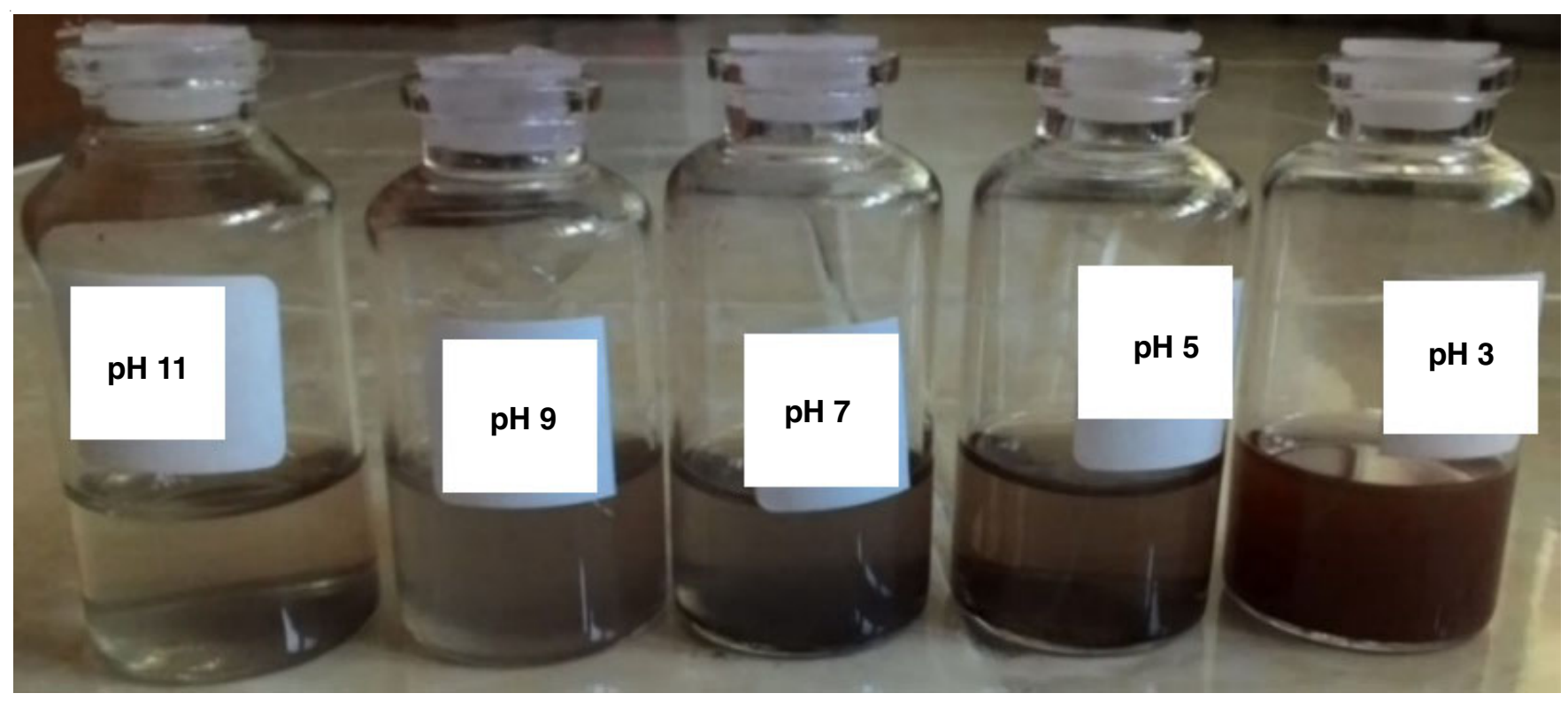

Fig. 1. Visual colour of citrate solution at various $\mathrm{pH}$ after irradiation process 


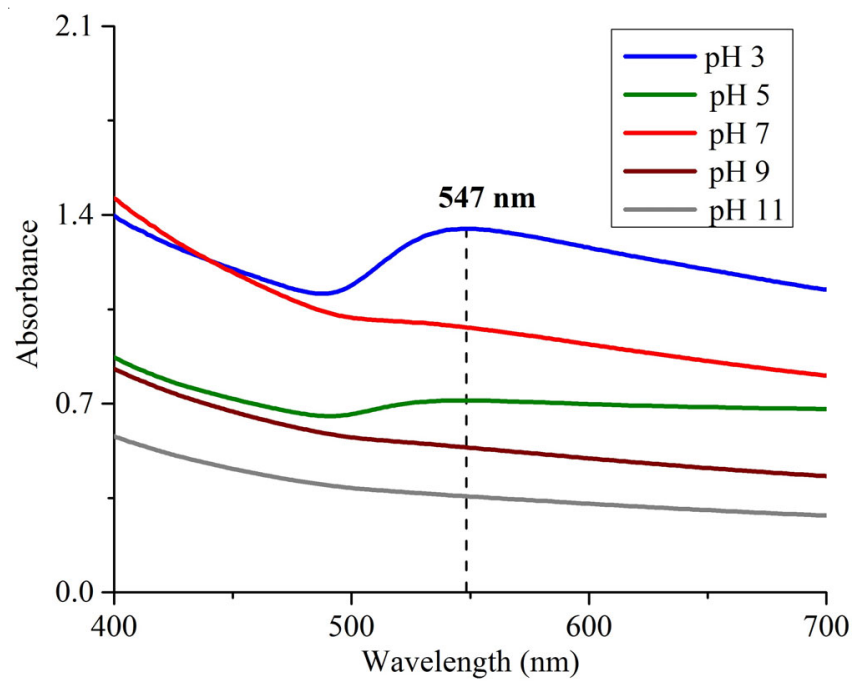

Fig. 2. UV-visible spectra of gold nanoparticles at various $\mathrm{pH}$ of sodium citrate

and the presence of fcc plane of $\mathrm{Au}(0)$ was identified. The three major peaks appear at $37.36,43.56$ and $63.86^{\circ}$, respectively indicates the planes of (111), (200) and (220) of fcc (Fig. 3). The diffractogram intensity of gold peaks after centrifugation is lower than the diffractogram of solid residue that contains both gold and Mg/Al HT-SA (Fig. 4). It was revealed that from the initial weight of Au as high as $10.9 \mathrm{mg}$, only $2.8 \mathrm{mg}$ (25.68 $\%$ ) of gold nanoparticles can be synthesized. This might due to the citrate anion only able to attract the smaller size of $\mathrm{Au}(0)$ and the rest of $\mathrm{AuCl}_{4}^{-}$. Through Debye-Scherrer equation (D $=\mathrm{K} \lambda /(\beta \cos \theta))$ [27], the average size of $\mathrm{Au}(0)$ from solid and from the centrifugation process with the respect was 36.86 and $24.44 \mathrm{~nm}$. The appearance of reduced gold at solid residue and gold nanoparticles were respectively shown by absorption band of FT-IR at 324 and $339 \mathrm{~cm}^{-1}$.

TEM image (Fig. 5) showed that polycrystalline phase of gold nanoparticles with the average size of gold nanoparticles is as high as $84.72 \mathrm{~nm}$. The nanoparticles size (Table-2) is bigger than the Debye-Scherrer equation. This might due to the agglomeration process during TEM preparation.

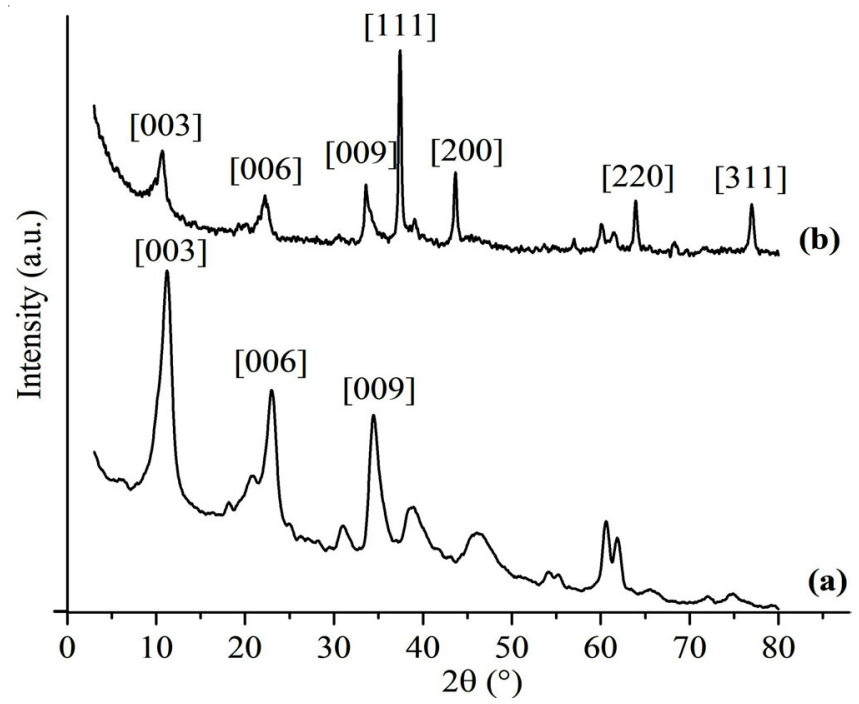

Fig. 3. XRD diffractogram of Mg/Al HT-SA (a) before and (b) after the sorption process of $\mathrm{AuCl}_{4}^{-}$

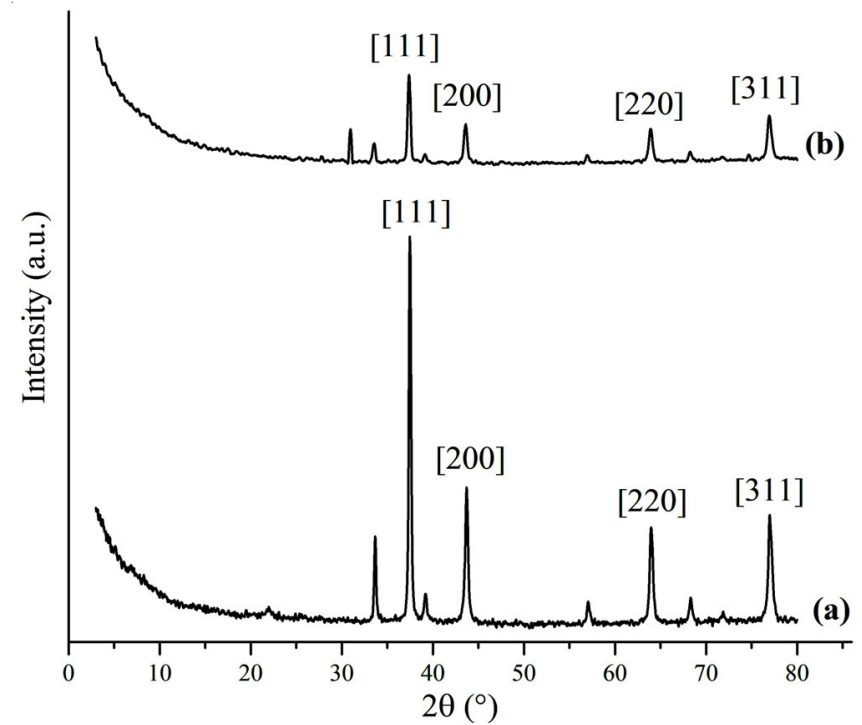

Fig. 4. XRD diffractogram of (a) solid residue and (b) synthesized gold nanoparticles

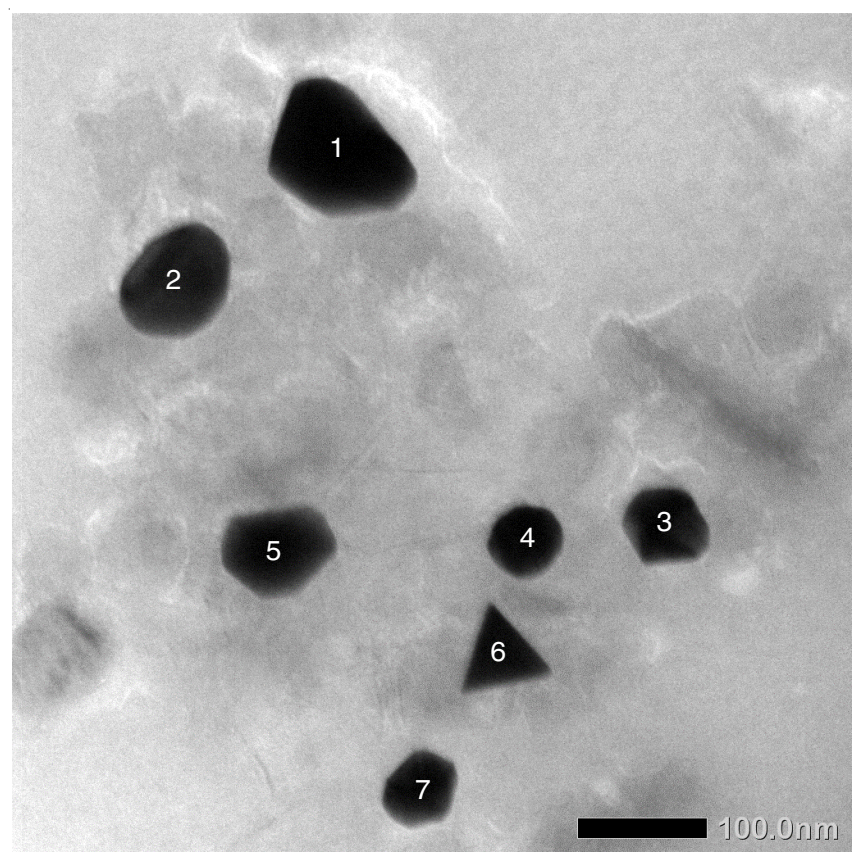

Fig. 5. TEM image of gold nanoparticles

TABLE-2

GOLD NANOPARTICLES SIZE MEASUREMENTS USING IMAGE-J SOFTWARE

\begin{tabular}{cc}
\hline Number of particle & Diameter \\
\hline 1 & 124.645 \\
2 & 99.252 \\
3 & 72.495 \\
4 & 63.399 \\
5 & 92.225 \\
6 & 75.664 \\
7 & 65.346 \\
\hline
\end{tabular}

Mechanism of the synthesis of gold nanoparticles: The possible mechanism of synthesis of gold nanoparticles had been postulated by Jimenez et al. [28], where the fast ligand exchange, the decarboxylation and the disproportionation process are the major reactions that driving the synthesis 
process. The reaction initiated by the reduction of $\mathrm{Au}(\mathrm{III})$ by sodium citrate to form $\mathrm{Au}(\mathrm{I})$. This includes a very fast exchange between a chloride ligand with a citrate anion followed by the deprotonation of alcohol and a slow decarboxylation process of the complex that makes $\mathrm{Au}(\mathrm{III})$ reduced into $\mathrm{Au}(\mathrm{I})$. The decarboxylation process is occurred slowly, means that this step is the determining step of reduction of $\mathrm{Au}(\mathrm{III})$ into $\mathrm{Au}(0)$ by citrate anion. The reaction ended by the disproportionation process which resulting of both $\mathrm{Au}(0)$ and $\mathrm{Au}(\mathrm{I})$ [28].

\section{Conclusion}

The present work highlight the important role of the medium acidity for preparing gold nanoparticles. In particular of the use of Turkevich method, the $\mathrm{pH}$ will highly depend to the $\mathrm{pKa}$ of the functional groups of citrate. The optimum $\mathrm{pH}$ will be likely at the range 3.0-5.0 where the most of carboxyl groups of citrate are deprotonated to form carboxylate anion. These anions, followed by phenolic group of citrate, are the responsible group to synthesis gold nanoparticles. The optimum $\mathrm{pH}$ obtained at this study was $\mathrm{pH}$ 3.0. The size distribution of single and polycrystal of synthesized gold nanoparticles were 24.44 and $84.72 \mathrm{~nm}$, respectively. The used citrate in this study has efficiency as high as $25.69 \%$.

\section{ACKNOWLEDGEMENTS}

This study is partly supported by the Directorate General of Higher Education of Republic of Indonesia through Penelitian Tim Pascasarjana (PTP) Research Grant Program 2018 with contract number: 1783/UN1/DITLIT/DIT-LIT/LT/2018.

\section{REFERENCES}

1. T. Zheng, S. Bott and Q. Huo, ACS Appl. Mater. Interfaces, 8, 21585 (2016); https://doi.org/10.1021/acsami.6b06903.

2. P. Priecel, H.A. Salami, R.H. Padilla, Z. Zhong and J.A. Lopez-Sanchez, Chinese J. Catal., 37, 1619 (2016); https://doi.org/10.1016/S1872-2067(16)62475-0.

3. H. Daraee, A. Eatemadi, E. Abbasi, S.F. Aval, M. Kouhi and A. Akbarzadeh, Artif. Cells Nanomed. Biotechnol., 44, 410 (2014); https://doi.org/10.3109/21691401.2014.955107.

4. J.F. Hainfeld, M.J. O'Connor, F.A. Dilmanian, D.N. Slatkin, D.J. Adams and H.M. Smilowitz, Br. J. Radiol., 84, 526 (2011); https://doi.org/10.1259/bjr/42612922.

5. S. Jain, D.G. Hirst and J.M. O'Sullivan, Br. J. Radiol., 85, 101 (2012); https://doi.org/10.1259/bjr/59448833.

6. A.J. Mieszawska, W.J. Mulder, Z.A. Fayad and D.P.Cormode, Mol. Pharm., 10, 831 (2013);

https://doi.org/10.1021/mp3005885.
7. N. Li, P. Zhao and D. Astruc, Angew. Chem. Int. Ed., 53, 1756 (2014); https://doi.org/10.1002/anie.201300441.

8. T. Ogata and Y. Nakano, Water Res., 39, 4281 (2005); https://doi.org/10.1016/j.watres.2005.06.036.

9. S.J. Santosa, S. Sudiono, D. Siswanta, E.S. Kunarti and S.R. Dewi, Adsorpt. Sci. Technol., 29, 733 (2011); https://doi.org/10.1260/0263-6174.29.8.733.

10. M. Rahmayanti, S.J. Santosa and Sutarno, Indones. J. Chem., 16, 329 (2016).

11. S. Okamoto and S. Hachisu, J. Colloid Interface Sci., 62, 172 (1977); https://doi.org/10.1016/0021-9797(77)90079-0.

12. L. Scarabelli, M. Grzelczak and L.M. Liz-Marzán, Chem. Mater., 25, 4232 (2013); https://doi.org/10.1021/cm402177b.

13. S.J. Santosa, E.S. Kunarti and Karmanto, Appl. Surf. Sci., 254, 7612 (2008); https://doi.org/10.1016/j.apsusc.2008.01.122.

14. S.J. Santosa, S. Sudiono and Z. Shiddiq, Effective Humic Acid Removal Using Zn/Al Layered Double Hydroxide Anionic Clay. J. Ion Exchange, 18, 322 (2007); https://doi.org/10.5182/jaie.18.322.

15. E. Heraldy, S.J. Santosa, Triyono and K. Wijaya, Indones. J. Chem., 15, 234 (2015).

16. I.Y. Ikhsani, S.J. Santosa and B. Rusdiarso, Indones. J. Chem., 16, 36 (2016).

17. L.I. Ardhayanti and S.J. Santosa, Procedia Eng., 148, 1380 (2016); https://doi.org/10.1016/j.proeng.2016.06.609.

18. D. Chen, Y. Li, J. Zhang, W. Li, J. Zhou, L. Shao and G. Qian, J. Hazard. Mater, 243, 152 (2012); https://doi.org/10.1016/j.jhazmat.2012.10.014.

19. P. Zhao, N. Li and D. Astruc, Coord. Chem. Rev., 257, 638 (2013); https://doi.org/10.1016/j.ccr.2012.09.002.

20. S. Kumar, K.S. Gandhi and R. Kumar, Ind. Eng. Chem. Res., 46, 3128 (2007); https://doi.org/10.1021/ie060672j.

21. D.M. Friedrich, Z. Wang, A.G. Joly, K.A. Peterson and P.R. Callis, J. Phys. Chem. A, 103, 9644 (1999); https://doi.org/10.1021/jp990405+.

22. W. Patungwasa and J.H. Hodak, Mater. Chem. Phys., 108, 45 (2008); https://doi.org/10.1016/j.matchemphys.2007.09.001.

23. J.-H. Lee, S.U.S. Choi, S.P. Jang and S.Y. Lee, Nanoscale Res. Lett., 7, 420 (2012); https://doi.org/10.1186/1556-276X-7-420.

24. A. Chauhan, B. Mittu and P. Chauhan, J. Anal. Bioanal. Technol., 6, 233 (2015); https://doi.org/10.4172/2155-9872.1000233.

25. A. Dhawan and J.F. Muth, Nanotechnology, 17, 2504 (2006); https://doi.org/10.1088/0957-4484/17/10/011.

26. D. Philip, Spectrochim. Acta A: Mol. Biomol. Spectrosc., 71, 80 (2008); https://doi.org/10.1016/j.saa.2007.11.012.

27. P. Prema, P.A. Iniya and G. Immanuel, RSC Adv., 6, 4601 (2016); https://doi.org/10.1039/C5RA23982F.

28. I. Ojea-Jimanez, F.M. Romero, N.G. Bastus and V. Puntes, J. Phys. Chem. C, 114, 1800 (2010); https://doi.org/10.1021/jp9091305. 